\title{
Polysèmes
}

Revue d'études intertextuelles et intermédiales

\section{Le Triptyque imaginaire de Piero di Cosimo dans Romola de George Eliot}

\section{Stéphanie Drouet-Richet}

\section{(2) OpenEdition}

Journals

Édition électronique

URL : http://journals.openedition.org/polysemes/1692

DOI : $10.4000 /$ polysemes. 1692

ISSN : 2496-4212

Éditeur

SAIT

Édition imprimée

Date de publication : 1 janvier 2007

Pagination : 21-34

ISSN : 0999-4203

\section{Référence électronique}

Stéphanie Drouet-Richet, «Le Triptyque imaginaire de Piero di Cosimo dans Romola de George Eliot », Polysèmes [En ligne], 8| 2007, mis en ligne le 01 janvier 2007, consulté le 20 avril 2019. URL : http:// journals.openedition.org/polysemes/1692 ; DOI : 10.4000/polysemes.1692

Ce document a été généré automatiquement le 20 avril 2019.

Polysèmes 


\title{
Le Triptyque imaginaire de Piero di Cosimo dans Romola de George Eliot
}

\author{
Stéphanie Drouet-Richet
}

1 Nous nous proposons d'étudier ici le motif central et récurrent du triptyque offert par Tito à Romola le jour de leur mariage, en le faisant d'abord dialoguer, comme le tableau semble lui-même le suggérer, avec son intertexte, qui est, nous le verrons, double. Le triptyque en question se présente selon cette perspective comme re-création, empruntant pour son élaboration des éléments particulièrement éloquents tout en les réassimilant et en les présentant sous un angle nouveau, s'écartant ainsi de la source pour mieux signifier.

2 Miroir de son siècle, fictivement conçu à une époque - la Renaissance florentine - ellemême profondément marquée par le retour aux sources classiques, mais artistiquement féconde et originale, le triptyque est création, peinture proleptique et prophétique : il possède en germe l'évolution future de l'héroïne et ponctue par des apparitions récurrentes son parcours religieux et spirituel, re-créant du sens nouveau à chaque occurrence. Pensé à l'origine par Tito comme récréation pour Romola, censé la détourner de ses inquiétudes, il se révèle vite présage sinistre, signe de tension, mais aussi indice d'une renaissance personnelle future.

3 La portée herméneutique de l'œuvre d'art ainsi soulignée est encore accrue par son environnement artistique, masques et tableaux, autant de faire-valoir qui en révèlent la vérité intrinsèque.

4 Telles sont les différentes strates d'interprétation, souvent imbriquées les unes dans les autres, que notre analyse tentera d'élucider.

\section{Le triptyque et ses intertextes : re-création}

Dès son apparition sur la scène romanesque, le triptyque lance le regard vers un horstexte de motifs figés retravaillés pour l'occasion par l'imagination de Tito, qui en est le commanditaire. 
6 Le tableau dont il est ici question est un triptyque peint par Piero de Cosimo sur les recommandations de Tito, représentant le mariage de Bacchus et d'Ariane - motif par ailleurs courant dans l'art de la Renaissance italienne (voir par exemple le célèbre Bacchus et Ariane du Titien) -, donc particulièrement bienvenu pour l'occasion, Tito voulant en faire présent à sa jeune épouse. Tito sera représenté en Bacchus, Romola en Ariane, puisque la ressemblance est également le vœu du jeune Grec.

7 La première question que le triptyque soulève est celle du choix de George Eliot quant à la forme même de cet objet pictural : un tableau à panneau unique n'aurait-il pu être tout aussi pertinent, et ce d'autant plus que seule une face en est ornée ? Outre le fait que le tabernacle creux pourra contenir un objet (détail essentiel pour la suite), le propre du polyptyque est qu'il peut se déployer et se refermer à loisir. Nous voyons par suite dans cet objet une invitation à ne pas nous en tenir à ce qui est peint à sa surface (ce qui est donné expressément à voir et, partant, attire le regard) et qui, déjà, signifie, mais à déplier métaphoriquement ses volets pour y découvrir le sens qu'ils recèlent. Il s'agirait donc en quelque sorte d'un pacte de lecture, suggérant de mettre à plat les replis du sens, d'en extirper ce qui se dérobe au regard. Le polyptyque, en incitant à pénétrer les mystères du pictural (nous employons à dessein ce terme connoté religieusement), en interroge l'évidence et en creuse le sens.

8 La description que fait Tito du triptyque à Piero di Cosimo, chargé de l'exécuter, nous renseigne sur son apparence extérieure. Contrairement au triptyque traditionnel, orné en son intérieur mais parfois simple façade de bois au dehors, seule la face externe est peinte, l'intérieur étant seulement recouvert de dorure: "The inside may be simple gilding: it is on the outside I want the device» $(244)^{1}$. Ce détail qui peut sembler secondaire a, nous le verrons, son importance. Le sujet en est le triomphe de Bacchus et d'Ariane, d'après les Métamorphoses d'Ovide. Tel est le projet imaginé par Tito :

'It is a favourite subject with you Florentines - the triumph of Bacchus and Ariadne; but I want it treated in a new way. A story in Ovid will give you the necessary hints. The young Bacchus must be seated in a ship, his head bound with clusters of grapes, and a spear entwined with vine-leaves in his hand; dark-berried ivy must wind about the masts and sails, the oars must be thyrsi, and flowers must wreathe themselves about the poop; leopards and tigers must be crouching before him, and dolphins must be sporting round.' $(244)^{2}$

Les échos mythologiques avec la source ovidienne sont aisément repérables mais cependant remaniés - transformés, pour emprunter au champ sémantique de la métamorphose -, Tito demandant non le respect fidèle de la légende, mais son adaptation à des fins strictement personnelles :

'But I want to have the fair-haired Ariadne with him, made immortal with her golden crown - that is not in Ovid's story, but no matter, you will conceive it all and above all there must be young Loves, such as you know how to paint, shooting with roses at the points of their arrows -' (244)

10 Le portrait condense en fait deux épisodes des Métamorphoses: d'une part le mariage du dieu et d'Ariane au livre VIII, d'autre part un épisode du livre III dans lequel Bacchus triomphe de l'équipage du bateau qui l'emmène vers Naxos pour retrouver Ariane et qui menace de le placer en esclavage. Le dieu vengeur y transforme l'équipage en dauphins et immobilise le navire en le couvrant de vignes et de chats ${ }^{3}$.

11 Le triptyque est évidemment ironique pour qui connaît l'histoire de Tito, qui a échappé aux pirates mais refuse de payer la rançon en échange de la liberté de son père adoptif, Baldassare. La trahison du père par le fils est donc ironiquement présente en filigrane 
dans le non respect de la source mythologique par le jeune homme. Par ailleurs, l'immortalité d'Ariane («made immortal», 244) figure bien dans le mythe: lorsque Bacchus trouve Ariane abandonnée et mourante sur l'île de Naxos et la ramène à la vie, il lui promet l'immortalité, principe de la renaissance de la végétation ${ }^{4}$. Tito, en insistant sur cet aspect du mythe, se voit donc sous les traits d'un sauveur pour Romola, qu'il arracherait à la vie quasi-carcérale qu'elle menait jusqu'alors chez son père, l'érudit Bardo. Il omet cependant délibérément toute référence à d'autres versions de la même légende qui mentionnent la mort d'Ariane, oubliée par Thésée sur Naxos et non point sauvée par Bacchus. Un autre pan du mythe est également laissé de côté, à savoir celui qui montre Ariane cette fois dans le rôle de la rédemptrice lorsqu'elle permet à Thésée de trouver la sortie du labyrinthe au moyen de son fil. Le projet artistique de Tito lui confère donc un rôle fictif qu'il n'endossera jamais dans le roman.

L'intertexte mythologique vient se doubler d'une autre strate intertextuelle, ajoutant une boucle supplémentaire à la spirale de sens précédemment créée. Si l'artiste choisi par Tito pour peindre le triptyque, Piero di Cosimo, a effectivement existé (il est en effet l'un des artistes figurant dans les Vies de Vasari), le tableau en question n'évoque directement aucune de ses œuvres connues, même si l'atmosphère et les motifs représentés sont cohérents avec l'œuvre de l'artiste. Animaux exotiques disparates - tigres, dauphins, léopards - et végétation luxuriante sont en effet caractéristiques de l'univers pictural onirique et fantastique de Piero di Cosimo, comme par exemple dans la toile intitulée L'Incendie de la forêt.

Deux tableaux authentiques du peintre pourraient toutefois avoir servi de source à George Eliot dans l'élaboration du triptyque, toiles ayant également pour sujet Bacchus et Ariane. La présence de ce palimpseste pictural éclairerait le sens du panneau commandé par Tito. Ces tableaux, peints par Piero pour le palais Vespucci à Florence ${ }^{5}$ et qui brossent l'histoire de l'humanité, des âges primitifs à la Renaissance ${ }^{6}$ sont La Découverte du miel d'une part, La Découverte du vin d'autre part. Le titre du second est suggéré par Felicia Bonaparte ${ }^{7}$, mais nous pensons qu'il s'agit plutôt des Mésaventures de Silène, tableau qui fait pendant au précédent dans l'œuvre du peintre florentin.

Bacchus apparaît sur la première des deux toiles comme un dieu bienveillant dispensateur de bienfaits pour l'humanité (voir illustration 1). Tel serait le Bacchus auquel Tito entend s'identifier. Le second tableau, Les Mésaventures de Silène (voir illustration 2), suggère cependant un aspect autrement plus sinistre de Dionysos, dieu potentiellement corrupteur et nuisible à la civilisation (au lieu de l'essaim d'abeilles escompté, Silène a trouvé un nid de guêpes qui lui piquent la tête; le tableau est par ailleurs dominé par des formes torturées évoquant le chaos). Notons que cette perversion était déjà préparée dans $L a$ Découverte du miel par la présence d'un personnage ivre (Silène) monté sur une mule aux côtés d'Ariane et de Bacchus, venant ainsi perturber l'apparente harmonie de la scène. Les références au double intertexte mythologique et pictural, potentiellement destructrices ou perturbantes, ou laissant le champ à un non-dit lourd d'implications, annoncent la portée prophétique du triptyque dans Romola.

\section{Le triptyque proleptique/prophétique}

15 Le triptyque est perçu par l'héroïne comme le reflet fidèle de son bonheur présent avec Tito, ainsi qu'en témoigne son identification avec le modèle représenté, version d'ailleurs entérinée par le narrateur : 
'And I am Ariadne, and you are crowning me! Yes, it is true, Tito; you have crowned my poor life.' They held each other's hands while she spoke, and both looked at their imaged selves. But the reality was far more beautiful [...]. (260)

Cette vision est également entretenue par Tito:

'[...] you will look every day at those pretty symbols of our life together - the ship on the calm sea, and the ivy that never withers, and those Loves that have left off wounding us and shower soft petals that are like our kisses, and the leopards and tigers, they are the troubles of your life that are all quelled now; and the strange sea- monsters, with their merry eyes - let us see - they are the dull passages in the heavy books.' (260)

Les éléments sinistres volontairement évacués par Tito lors de la conception du triptyque mais cependant présents en filigrane dans l'intertexte du tableau finiront par ressortir au grand jour. Le projet est d'ailleurs vicié dès sa conception par les véritables motivations de Tito, qui envisage, avec le pragmatisme qui le caractérise, le tableau comme un subterfuge destiné à masquer la vente de la bague qui lui aurait permis de payer la rançon de Baldassare : « $[\mathrm{H}] \mathrm{e}$ would carry out a pretty ingenious thought which would set him more at ease in accounting for the absence of his ring for Romola » (242). Le caractère illusoire de la peinture ornant sa face externe est par ailleurs rapidement et dramatiquement mis à nu par l'apparition d'une mascarade macabre mise en scène, il faut le noter, par le même Piero di Cosimo, qui vient troubler la cérémonie nuptiale, funeste présage de l'avenir désastreux de cette union :

And as they spoke there came slowly into view [...] a huge and ghastly image of the Winged Time with his scythe and hour-glass, surrounded by his winged children, the Hours. He was mounted on a high car completely covered with black, their horns alone standing out white above the gloom; so that in the sombre shadow of the houses it seemed to those at a distance as if Time and his children were apparitions floating through the air. And behind them came what looked like a troop of the sheeted dead gliding above blackness. And as they glided slowly, they chanted in a wailing strain. $(262)^{8}$

L'apparition du masque de Chronos avec son cortège de connotations lugubres vient radicalement contredire l'atemporalité de la scène pastorale peinte sur le triptyque, tout en faisant écho à la vision prophétique cataclysmique du frère de Romola9 ${ }^{9}$.

Les chapitres 36, "Ariadne Discrowns Herself» et 37, "The Tabernacle Unlocked " renversent diamétralement la perspective instaurée au chapitre 20 lors du don du cadeau à la fiancée. Lorsque Romola ouvre le triptyque pour le contempler à nouveau, le contexte est tout autre que dans la scène initiale.

Elle a désormais perdu ses illusions sur son mariage et sur Tito, dont elle a découvert la traitrise : malgré la promesse faite à Romola, Tito a mis en vente à l'insu de son épouse la bibliothèque de son père, Bardo. Voici le même triptyque désormais filtré à travers le regard dessillé de l'héroïne :

The pale morning light fell upon it so as to make the painted forms discernible enough to Romola, who knew them well, - the triumphant Bacchus, with his clusters and vine-clad spear, clasping the crowned Ariadne; the Loves showering roses, the wreathed vessel, the cunning-eyed [et non plus «merry eyes » comme précédemment] dolphins and the rippled sea; all encircled by a flowery border, like a bower of paradise. Romola looked at the familiar images with new bitterness and repulsion: they seemed a more pitiable mockery than ever [...]. (397)

Le commentaire narratorial précédemment évoqué selon lequel la réalité est plus belle que sa copie peinte (« reality was far more beautiful »,260) prend ici toute sa dimension ironique : 
Foolish Ariadne! with her gaze of love, as if that bright face, with its hyacinthine curls like tendrils among the vines, held the deep secret of her life! 'Ariadne is wonderfully transformed,' thought Romola. 'She would look strange among the vines and the roses now.' (397-398)

21 Là encore, l'allusion ironique aux Métamorphoses ovidiennes est à peine voilée, comme le triptyque devient le faire-valoir à l'aune duquel se mesure la métamorphose d'Ariane. Ironiques également les paroles prononcées par Tito remettant son cadeau à Romola :

'It is a little shrine, which is to hide away from you for ever that remembrance of sadness. You have done with sadness now, and we will bury all images of it - bury them in a tomb of joy.' (259)

L'expression volontairement ambiguë «tomb of joy » (nous soulignons) - tombeau de joies/tombeau pour les joies - prend tout son sens avec le recul et le commentaire lucide de Romola : « They have been no tomb of sorrow, but a lying screen » (397). Si le triptyque n'a effectivement pas enseveli ses peines, il a bien été un tombeau pour ses joies. Le renversement de la perspective est également perceptible dans les échos vestimentaires qui parcourent les deux chapitres. La Romola radieuse en robe de mariée, à la beauté préraphaélite -

Romola entered, all white and gold, more than ever like a tall lily. Her white silk garment was bound by a golden girdle, which fell with large tassels; and above that was the rippling gold of her hair, surmounted by the white mist of her long veil, which was fastened on her brow by a band of pearls [...] and was now parted off her face so that it all floated backward. (258-259)

- est maintenant prête à endosser un déguisement de religieuse ( she turned away her eyes from the white and gold to the dark bundle, and as her hands touched the serge, her tears began to be checked », 389), la parure d'apparat ayant été reléguée dans une malle et l'alliance ôtée (« The white silk and gold lay there, the long white veil and the circlet of pearls [...]: they seemed the shroud of her dead happiness ", ibid.). La symbolique du tombeau inaugurée par le triptyque est encore présente dans cette image du renoncement et de la mort à soi-même.

Le triptyque est d'ailleurs explicitement désigné par des termes connotés religieusement : il est châsse («shrine») ou tabernacle. Vide en son cœur, il est destiné à recevoir le crucifix remis par Savonarole à Romola lors de la mort de son frère Dino, frère dominicain. Grâce à cet objet, le triptyque devient dépositaire de deux idéologies : celle de la surface peinte, ouvertement païenne (allusion à l'apparence trompeuse de Tito), celle de l'intérieur, chrétienne, où repose le crucifix. Il annonce alors les tensions qui vont habiter Romola et les pôles entre lesquels elle va osciller, entre l'hédonisme païen de Tito et la religiosité austère de Savonarole.

Comble de l'ironie, c'est Tito en personne qui dépose, ou plutôt fait disparaître le crucifix dans le tabernacle, signifiant par ce geste son intention de faire triompher les valeurs bacchiques sur celles incarnées par Dino: «He opened the triptych and placed the crucifix within the central space [...] setting the little tabernacle in the spot where the crucifix had stood» (259-260). La tension entre christianisme et paganisme transparaît déjà dans un passage antérieur, portrait de Tito focalisé par Romola alors qu'elle vient de rendre visite à son frère mourant, qui préfigure le triptyque avant même sa réalisation ainsi que le futur portrait de Tito sous les traits de Bacchus - description à fort caractère pictural qui n'est pas sans évoquer Bacchus et Ariane par le Titien :

She saw the rich dark beauty which seemed to gather round it all images of joypurple vines festooned between the elms, the strong corn perfecting itself under 
the vibrating heat, bright winged creatures hurrying and resting among the flowers, round limbs beating the earth in gladness with cymbals held aloft, light melodies chanted to the thrilling rhythm of strings - all objects and all sounds that tell of nature revelling in her force. Strange, bewildering transition from those pale images of sorrow and death to this bright youthfulness, as of a sun-god who knew nothing of night! (238, nous soulignons)

Le symbolisme du crucifix placé dans le tabernacle, soustrait au regard de Romola par Tito - «it is hidden - hidden by these images of youth and joy", 261 - resurgit régulièrement dans la diégèse, marque de l'attachement croissant de Romola aux valeurs incarnées par Savonarole ${ }^{10}$. Emporté par elle lors de sa première fuite, le crucifix symbolise la mémoire et matérialise l'évolution spirituelle de l'héroöne. Il est le signe d'un changement irréversible (" the sign of an irreversible change », 398). Utilisé au chapitre 40 par Savonarole, il indique le chemin à suivre, celui du sacrifice : « 'Conform your life to that image, my daughter; make your sorrow an offering' » (433). La ferveur religieuse de Romola se manifeste lors d'une procession florentine au passage d'un autre tabernacle, non décoré, mais recélant dans ses profondeurs, jamais offertes aux regards, l'image de la Vierge Miséricordieuse, «the Unseen Madonna », allusion au chapitre suivant où Romola est elle-même comparée à une Madone, visible celle-là ("Visible Madonna »).

Le conflit entre les deux pôles est cependant trop violent en Romola pour que le triptyque païen soit totalement et définitivement supplanté par une icône religieuse. Révoltée par la vision de Camilla Rucellai, en proie à des doutes croissants quant à l'intégrité morale de Savonarole, Romola tente en vain de trouver l'apaisement devant un tableau de Filippino Lippi représentant la Vierge apparaissant à Saint Bernard ${ }^{11}$. Entre les extrêmes incarnés par Tito et Savonarole, entre le triptyque ovidien et la peinture religieuse, il s'agit de trouver le juste milieu :

What thought could reconcile that worn anguish in her brother's face - that straining after something invisible - with this satisfied strength and beauty, and make it intelligible that they belonged to the same world? Or was there never any reconciling them, but only a blind worship of clashing deities, first in mad joy and then in wailing? (238)

Ce n'est qu'au prix d'une réconciliation, voire d'un compromis entre les pôles païen et chrétien que Romola pourra enfin renaître à elle-même.

Une autre peinture prophétique, qui fait écho au triptyque de Romola, nous parait renfermer les mêmes forces contradictoires entre lesquelles Florence et par là-même Romola sont tiraillées. Il s'agit de la représentation des Trois Masques esquissée par Piero di Cosimo, œuvre cette fois fictive, mais directement inspirée des Vies de Vasari ${ }^{12}$. Le dessin est composé de trois visages :

[...] one a drunken laughing Satyr, another a sorrowing Magdalen, and the third, which lay between them, the rigid, cold face of a Stoic: the masks rested obliquely on the lap of a little child, whose cherub features rose above them with something of the supernatural promise in the gaze [...]. (79, nous soulignons)

Bien qu'énigmatique, l'esquisse semble suggérer une lecture spirituelle, à contraster avec l'interprétation hédoniste réductrice qu'en propose $\mathrm{Tito}^{13}$. Les trois masques représenteraient respectivement Tito/Bacchus, Savonarole et Bardo, à savoir les trois philosophies s'offrant à Romola ainsi qu'à Florence. Quant à l'enfant, il serait le symbole d'une quatrième voie, synthèse des trois autres, promesse que Romola doit s'approprier ${ }^{14}$.

Le triptyque, nous l'avons vu, reflète fortement l'idéologie de Tito. S'il livre du sens, c'est moins directement que de façon oblique, par ses silences et par le contexte de ses 
apparitions successives - ainsi que par le dialogue qui s'instaure avec d'autres œuvres artistiques participant de la diégèse, avec lesquelles il peut implicitement être mis en relation.

Aussi, Sinon Deceiving Priam, tableau dont nous suivons progressivement l'exécution par Piero di Cosimo, apparaît comme le revers du triptyque ovidien représentant Bacchus et Ariane - sa face cachée, son envers, sa vérité, en quelque sorte. L'esquisse est d'ailleurs première chronologiquement et est censée servir de modèle au portrait de Tito en Bacchus dans le triptyque. Sinon Deceiving Priam, également tableau prophétique et palimpseste en cela qu'il est retouché à plusieurs reprises par le peintre à mesure de l'évolution de son modèle, fixe Sinon/Tito (puisque c'est ce personnage que le peintre choisit de façon on ne peut plus appropriée comme modèle pour son traitre) dans une attitude diamétralement opposée à celle du Bacchus triomphant dans le tabernacle voulu par Tito :

Piero turned the sketch, and held it toward Tito's eyes.

He saw himself with his right hand uplifted, holding a wine-cup, in the attitude of triumphant joy [allusion au triptyque], but with his face turned away from the cup with an expression of such intense fear in the dilated eyes and pallid lips, that he felt a cold stream through his veins, as if he were being thrown into sympathy with his imaged self.

'You are beginning to look like it already,' said Piero [...].

(247, nous soulignons $)^{15}$

31 Le tableau renverse visiblement la perspective flatteuse suggérée par le triptyque, présentant ici Tito/Bacchus sous un jour moins favorable, révélant par le biais de la représentation picturale sa véritable nature, celle d'un dissimulateur et d'un traître, à la beauté corrompue par la peur et la culpabilité. Le tableau Sinon Deceiving Priam souligne donc le pouvoir de 'dénudation'16 que peut posséder l'image, ainsi que le regard pénétrant et clairvoyant de l'artiste, qui est le mieux à-même de saisir le quasi-imperceptible, à savoir la pâleur subite de Tito lorsqu'il se trouve inopinément face à son père, et de fixer pour l'éternité sur la toile une attitude fugace. Sinon Deceiving Priam, regard posé par l'artiste sur Tito, sera d'ailleurs l'un des agents décisifs de la prise de conscience de Romola quant à la personnalité multiple de son mari - de sa naissance à la lucidité en quelque sorte - lorsqu'elle découvrira par inadvertance le tableau dans l'atelier de Piero.

Le triptyque sur lequel est centrée cette étude doit à l'évidence être réintégré dans un réseau complexe d'allusions et d'échos si l'on veut tenter d'en comprendre la signification ainsi que la fonction dans l'économie d'ensemble de Romola. Les liens que nous avons tenté de mettre au jour ici ne sont bien sûr pas exhaustifs, mais montrent la richesse de cette inclusion du pictural dans le texte. Le triptyque ne remplit certes pas une simple fonction décorative. Il permet à lui seul, et en dialogue avec les autres intertextes, qu'ils soient mythologiques et/ou picturaux d'éclairer, voire de révéler (car telle est la fonction de la peinture prophétique) des pans entiers de l'œuvre.

Une telle approche semble particulièrement adaptée à une œuvre telle que Romola, qui foisonne de détails visuels et iconiques, dans le cadre symbolique de la Renaissance, période de renouveau mais aussi de réappropriation du passé. L'exemple du triptyque pourrait, nous semble-t-il, tout aussi bien emblématiser la technique créative de George Eliot, qui assigne régulièrement à l'art une place de choix dans sa fiction, lui conférant une fonction herméneutique et symbolique résumée par cette citation célèbre de la romancière : 
The greatest benefit we owe to the artist, whether painter, poet, or novelist, is the extension of our sympathies [...]. Art is the nearest thing to life; it is a mode of amplifying experience and extending our contact with our fellow-men beyond the bounds of our personal lot. ${ }^{17}$

Romola est parfois considéré comme le plus victorien des romans de George Eliot. Les préoccupations morales et sociales qui animent l'époque trouble de la fin du quinzième siècle florentin ressemblent fort à celles de la romancière et de ses contemporains : puritanisme moral et religieux, relation entre individu et société, etc. sont également sujets à controverses à l'époque victorienne. Le "Proem » du roman, développant un thème cher aux Victoriens, souligne les liens entre le passé et le présent, insistant sur une continuité historique qui semble pourtant quelque peu malmenée dans Romola. Dans une ville tourmentée par les soubresauts politiques, Tito ne peut être Bacchus, ni Romola Ariane. Ce ne sont donc pas les événements historiques spécifiques à l'Italie du Quattrocento qui recueillent l'attention de la romancière, mais plutôt les choix moraux auxquels est confronté l'homme, question qui transcende les contingences purement historiques pour se recentrer sur le développement, la naissance à soi, de l'individu pierres de touche des futurs 'grands' romans de l'écrivain, Middlemarch et Daniel Deronda.

\section{BIBLIOGRAPHIE}

ELIOT, George. Romola (1863). Harmondsworth: Penguin, 1980.

ELIOT, George. Selected Critical Writing. Oxford: OUP, 1992.

BONAPARTE, Felicia. The Triptych and the Cross. The Central Myths of George Eliot's Poetic Imagination. New York: New York UP, 1979.

BULLEN, J.B. The Myth of the Renaissance in Nineteenth Century Writing. Manchester: Manchester UP, 1994.

FORLANI TEMPESTI, A.F., CAPRETTI, E. Piero di Cosimo (trad. B. Comment et F. Pasquet). Paris : Éditions du Félin, 1996.

OVIDE. Les Métamorphoses. Traduction, introduction et notes par Joseph Chamonard. Paris : Garnier Flammarion, 1969.

VASARI, Giorgio. Lives of the Most Eminent Painters, Sculptors and Architects (trans. Mrs Jonathan Foster). vol. II. London: George Bell and Sons, 1878.

WITEMEYER, Hugh. George Eliot and the Visual Arts. New Haven and London: Yale UP, 1979.

\section{NOTES}

1. Les numéros de pages renvoient à l'édition citée en bibliographie.

2. Ce sont en effet des panthères et des tigres qui tirent traditionnellement le char couronné de fleurs de Dionysos. 
3. Ovide, Métamorphoses, traduction, introduction et notes par Joseph Chamonard, Paris : Garnier Flammarion, 1969, livre III, 107.

4. Ibid., 107.

5. Voir également la ressemblance frappante entre la description de Romola et le tableau Simonetta Vespucci par Piero di Cosimo, commandé par le même Vespucci.

6. Selon Ovide (Fastes, III) Bacchus fut le premier à découvrir le miel et à enseigner aux hommes les rituels religieux et les plaisirs simples de la vie pastorale. Piero di Cosimo représente donc, dans La Découverte du miel, les apports d'un dieu, Bacchus, à la civilisation humaine. La ville, située à gauche de la toile, symbolise la civilisation dont Bacchus est le représentant, tandis que la colline sauvage, à droite, fait allusion à la condition primitive dans laquelle vivent Silène et les satyres. Le tableau comporte des éléments parodiques du texte d'Ovide, comme les ustensiles de cuisine brandis par le cortège qui suit Bacchus au lieu d'instruments de laiton comme le voudrait le texte antique.

7. Felicia Bonaparte, The Triptych and the Cross. The Central Myths of George Eliot's Imagination, New York: New York UP, 1979, 88-89.

8. L'épisode fait allusion à une authentique mascarade carnavalesque organisée par le peintre Piero di Cosimo, dont le goût pour de telles manifestations est rapporté par Vasari (voir Vies, 416-417). Le char en question s'intitulait « Le Triomphe de la Mort ».

9. Voir Romola, 215-216.

10. L'image du triptyque trompeur dissimulant le crucifix est reprise par Savonarole pour qui la lampe de la Vérité est enfouie dans le tombeau de l'Église corrompue qu'il a pour mission de régénérer : "He believed that God had committed to the Church the sacred lamp of truth for the guidance and salvation of men, and he saw that the Church, in its corruption, had become a sepulchre to hide the lamp» (271).

11. "Calmness would not come even on the altar-steps; it would not come from looking at the serene picture where the saint, writing in the rocky solitude, was being visited by faces with celestial peace in them. Romola was in the hard press of human difficulties, and that rocky solitude was too far off » (528). Ce n'est en effet pas dans le désert de la solitude que Romola trouvera son accomplissement (la description finale de l'héroïne en souligne la nouvelle sérénité, proche de celle des figures célestes du tableau religieux), mais dans la relation avec autrui et l'ouverture sur le monde extérieur (674).

12. Giorgio Vasari, Lives of the Most Eminent Painters, Sculptors and Architects (trans. Mrs Jonathan Foster), vol. II, London: George Bell and Sons, 1878, 415 : « He would sometimes stand beside a wall, against which various impurities were cast, and from these he would image forth the most singular scenes [...]».

13. "The child, perhaps, is the Golden Age, wanting neither worship nor philosophy. [...] Or, the child may mean the wise philosophy of Epicurus, removed alike from the gross, the sad, and the severe » (79).

14. L'esquisse éveillerait ainsi selon cette dernière interprétation les mêmes sentiments que le campanile de Giotto aux yeux du narrateur : «a prophetic symbol, telling that human life must somehow and some time shape itself into accord with that pure aspiring beauty » (76).

15. Il convient de noter dans cette remarque du peintre le renversement de perspective entre le spectateur et son image peinte, inversion qui aboutit au brouillage des frontières entre animé et inanimé. Le tableau préfigure également l'attitude de Tito, pétrifié de terreur par l'intrusion de Baldassare lors du banquet dans les jardins Rucellai.

16. Le terme est emprunté à Georges Didi-Huberman dans son ouvrage Devant l'image. Question posée aux fins d'une histoire de l'art, Paris : Éditions de Minuit, 231.

17. George Eliot, «The Natural History of German Life », in Selected Critical Writings, Oxford: OUP, 1992, 263-64.

Polysèmes, 8 | 2007 
INDEX

oeuvrecitee Romola 